\title{
The Use of Human Tumor Cells Grown in Multicellular Spheroid Culture for Designing and Improving Therapeutic Strategies
}

\author{
H. ACKER \\ Max Planck Institut für molekulare Physiologie, Rheinlanddamm 201, D-44139 Dortmund, FRG
}

(Received I October 1996; In final form 26 June 1997)

\begin{abstract}
Human tumor cells grown in threedimensional multicellular spheroid culture represent an ideal system to study the heterogeneous interaction between microenvironment and different therapeutic modalities in patients. Overcoming this heterogeneity is the most challeging task for the improvement of cancer therapy. Examples of this interaction are given with the meaning of $\mathrm{pO}_{2}$ and $\mathrm{pH}$ for the treatment of tumor cells with radiation, cytostatics, cytokines and gene therapy. The presented results might form a base for the use of multicellular spheroids in a concerted action between clinicians, biologists and mathematicians to improve tumor therapy individually for each patient.
\end{abstract}

Keywords: Human tumour cells, multicellular spheroids, metabolism, radiation, interferon, doxorubicin, gene therapy, oxygen sensing, angiogenesis, $\mathrm{pO}_{2}, \mathrm{pH}$, confocal microscopy, microelectrodes

\section{INTRODUCTION}

It is now generally accepted that microenvironmental conditions like $\mathrm{pO}_{2}$, tissue level of nutrition factors or $\mathrm{pH}$ are influencing tumor growth, metabolism and therapeutic sensitivity (Sutherland 1988). However, the relative importance of these factors, their interactions and their influence on growth and therapeutic response are not well understood. It is likely that several microenvironmental parameters are working together in a complex manner leading to heterogenous therapy outcomes. Diffusion limitation or decreased blood flow in a tumor will lead to nutrient deficiency, hypoxia, increased acidosis in the microenvironment and production of toxic factors in necrotic zones. These factors induce changes of metabolic as well as microenvironmental characteristics in tumor cell regions and will probably influence basic cell functions such as cellular communication, gene regulation, cell structure and cell cycle distribution (Sutherland et al. 1988). The present article describes various human tumor cells grown in threedimensional multicellular spheroid culture as a model to study the interaction of microenvironmental conditions with different therapeutic modalities like radiation, cytostatica,

Tel: 0231-1206-530; Fax: 0231-9023374; E-mail: helmut.acker@mpi-dortmund.mpg.de. 
cytokines and gentherapy. These recent findings might be usefull for clinicians to improve individually therapeutic schemes for each patient, for biologists to prove the validity of findings on the molecular level in an in vitro model without the need of animal experiments and for mathematicians to model complex interactions between microenvironment and therapy as well as to design on this base new therapeutic schemes.

\section{RESULTS AND DISCUSSION}

\section{The Model (Cell Cycle Characteristics, Glucose and Oxygen Supply, pH, Growth Rate, Cell Vitality, Cell Death)}

To study the relation between microenvironmental conditions and therapeutic outcome, tumor cells can be cultured in the form of three-dimensional multicellular spheroids (MS). MS are nearly spherical aggregates of tumor cells in tissue culture growing to a diameter of about $1 \mathrm{~mm}$. They are used as models of poorly vascularized tumor nodules and in contrast to tumor cells in monolayer culture they reveal a sensitivity for radiation - and chemotherapy-treatment comparable to tumor cells in vivo (Sutherland 1988, Müller-Klieser 1987). MS possess radial $\mathrm{pO}_{2}$ - as well as radial extracellular $\mathrm{pH}-$ gradients with low values in the center and proliferation gradients with cells in the $S$ or $G_{2}$ phase in the periphery and cells in the $G_{1}$ phase in deeper cell layers followed by quiescent cells or necrotic cells in the centre (Görlach et al. 1995, Görlach and Acker 19494).

This heterogeneity in cell vitality can be studied and visualized by confocal laser scanning micoscopy (CLSM) of fluorescence dyes indicating cell vitality or cell death in MS (Wartenberg and Acker 1996). This non-invasive technique determines the fluorescence distribution of cells stained with vital (calcein/AM, FDA) or lethal (LYVS) dyes in radial recordings of the fluorescence intensity at distinct depth of the MS as shown in Figure 1 for human malign glioma cells U 343 MG. Vital cell stains were loaded as acetoxymethylesters (AM-esters) which are lipophilic and passively permeate cell membranes. In the cell they are converted by intracellular esterases to polar fluorescent molecules and trapped in the cytoplasmic compartment. LYVS as a highly charged tracer binds to sulhydryl groups of proteins in dead cells. MS up to a diameter of $250 \mu \mathrm{m}$ were homogeneously stained with vital fluorescence dyes giving a rim thickness of viabel cells between $64 \mu \mathrm{m}$ and $125 \mu \mathrm{m}$. Figure 1 shows furthermore that necrosis develops with increasing MS diameter as visualized by LYVS. The critical diameter at which central necrosis occurred first was about $700 \mu \mathrm{m}$ for glioma $\mathrm{U} 118 \mathrm{MG}$ and about $500 \mu \mathrm{m}$ for glioma U 251 MG (Haji-Karim and Carlsson 1978). In glioma $343 \mathrm{MG}$ spheroids we observed first signs of central cell death at a diameter of $400 \mu \mathrm{m} \pm 25$. The thickness of the vital stained rim reached the lowest level with $64 \mu \mathrm{m} \pm 7$ in MS of a size class of $550 \mu \mathrm{m} \pm 25$. At the maximum thickness of the vital stained rim no unstained cell area was observed. In contrast MS of the size class $550 \mu \mathrm{m} \pm 25$ showed a $150 \mu \mathrm{m}$ rim of unstained cells. These unstained cells with a rim thickness between $50 \mu \mathrm{m}-150 \mu \mathrm{m}$ might be comparable with subpopulations of quiescent cells in MS as described by Sutherland (1988) and Bauer et al. (1982). The lack of staining might be related to a P-glycoprotein mediated multi-drug resistance (Neyfakh 1988, Liminga et al. 1994). The whole shell of vital cells in MS U 343 MG (FDA and Calcein/AM stained and unstained cells) varied between $126 \mu \mathrm{m}$ and $214 \mu \mathrm{m}$. These results are in good agreement with the work of Haji-Karim and Carlsson (1978) on U 251 MG glioma MS and supplement the study of Durand (1990) by observing a reincrease of the thickness of the rim of vital stained cells in MS bigger than $500 \mu \mathrm{m}$.

As MS are avascular tissue nodules oxygen and $\mathrm{H}^{+}$diffusion gradients develop due to oxygen consumption and glycolytic breakdown of glucose to lactate leading to relatively symmetric $\mathrm{pO}_{2}$ and $\mathrm{pH}$ gradients inside the spheroids. Microelectrode measurements of those gradients in MS are now well established techniques giving reliable and reproducible values (see for review Acker et al. 

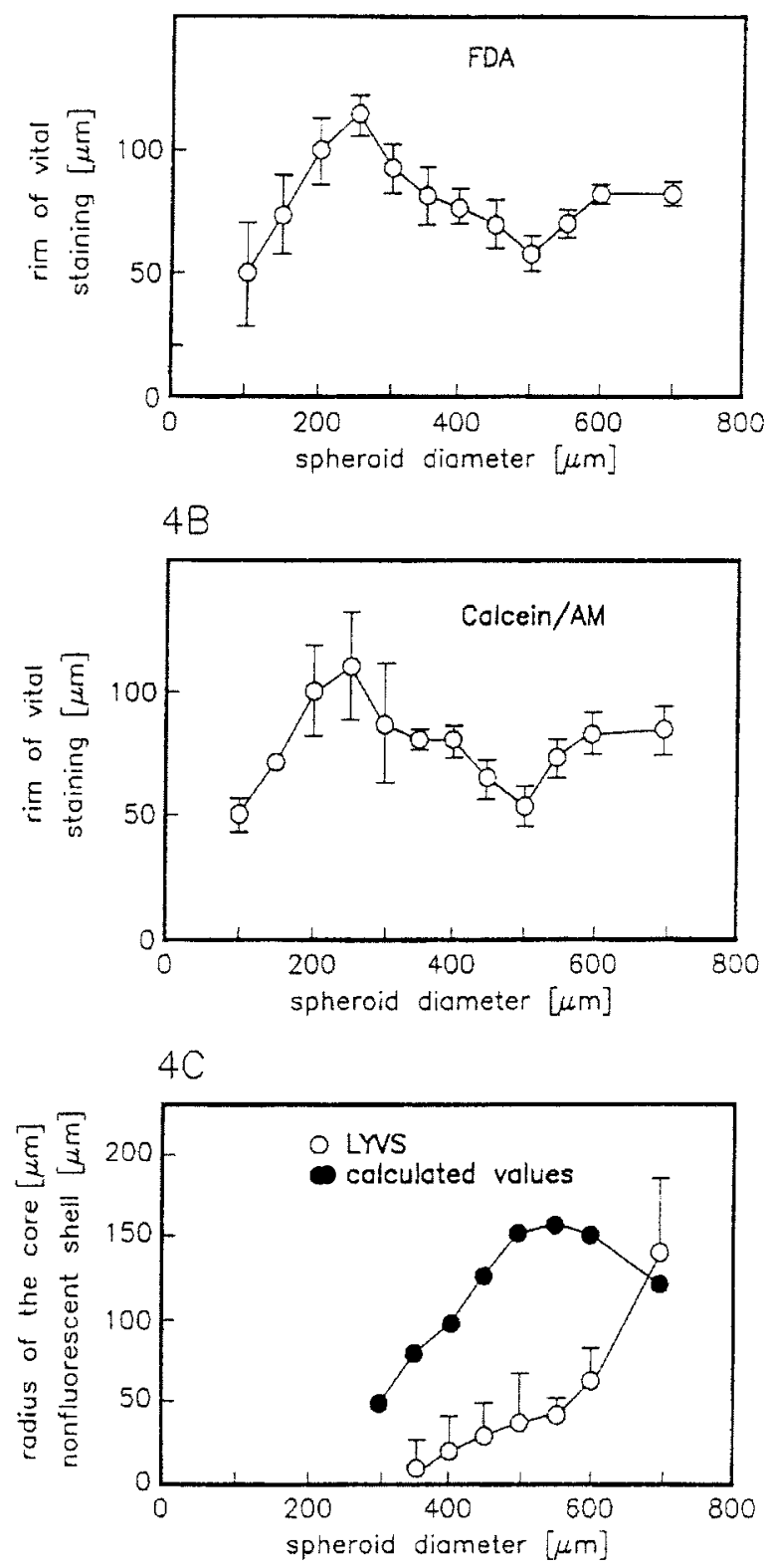

FIGURE 1 Quantitative vital/lethal assay after radial fluorescence recording by confocal laser microscopy in MS of different size groups. (A,B): Thickness of the rim of peripheral vital dye fluorescence due to the diameter of MS. MS were incubated for 120 min at $8{ }^{\circ} \mathrm{C}$ with Calcein/AM or with FDA and were examined after $10 \mathrm{~min}$ at $37^{\circ} \mathrm{C} . n=10$ for every mean value. (C): Radius of the central lethal dye fluorescence after staining with LYVS due to the diameter of the glioma MS (holow circles). $n=6$ for every mean value. The thickness of the nonfluorescent shell (filled circle) was calculated from the thickness of the vital dye fluorescence, the radius of the central dye fluorescence and the radius of MS (Wartenberg and Acker 1996).

1984, Bjerkvig 1992). The relation of $\mathrm{pO}_{2}$ - and $\mathrm{pH}$-gradients to cellular metabolism has been investigated intensively in HT29 human colon carcinoma tumor cells and U118MG human malign glioma cells grown as MS with diameter between
600 and $800 \mu \mathrm{m}$ (Görlach et al. 1995). $\mathrm{pO}_{2}$ measurements in HT29 spheroids revealed steep $\mathrm{pO}_{2}$ gradients with $\mathrm{pO}_{2}$ decreases between spheroid surface and center $\left(\Delta \mathrm{pO}_{2}\right)$ of $107 \mathrm{mmHg} \pm 9(n=$ 17) leading to central values of $6 \mathrm{mmHg} \pm 5$. In 
U118MG spheroids with well oxygenated centers exhibiting central $\mathrm{pO}_{2}$ values of $47 \mathrm{mmHg} \pm 21$ flatter $\mathrm{pO}_{2}$ gradients with surface-center differences $\left(\Delta \mathrm{pO}_{2}\right)$ of $78 \mathrm{~mm} \mathrm{Hg} \pm 24(n=10)$ were recorded. $\mathrm{pH}$ gradients, however, were significantly steeper $(p<0.005)$ in U118MG spheroids with central $\mathrm{pH}$ values of $6.93 \pm 0.09(n=15)$ and $\Delta \mathrm{pH}$ values of $0.36 \pm 0.09$ than in HT29 spheroids with central $\mathrm{pH}$ values of $7.07 \pm 0.06(n=17)$ and $\mathrm{pH}$ decreases of $0.28 \pm 0.06$. Figure 2 demonstrates the frequence distribution of $\mathrm{pO}_{2}$ and $\mathrm{pH}$ values of HT29 and U $118 \mathrm{MG}$ MS with the significant differences in the mean $\mathrm{pO}_{2}$ and $\mathrm{pH}$. High lactate production in U118MG spheroids in contrast to HT29 spheroids with a high oxygen consumption has been described by Carlsson and Acker (1988) confirming the measured $\mathrm{pO}_{2}-$ and $\mathrm{pH}$-gradients. The findings of Figure 2 are in also in agreement with higher oxidative metabolic activity monitored in HT29 cells and high LDH activity measured in U118MG spheroid homogenates as estimated by the incorporation rates of $1-$ and $2-14 \mathrm{C}$ pyruvate (Görlach et al. 1995). Thus the complex $\mathrm{pO}_{2}$ versus $\mathrm{pH}$ relationship as measured in HT29 spheroids indicates high oxygen consumption whereas the $\mathrm{pO}_{2}$ versus $\mathrm{pH}$ relationship as measured in $\mathrm{U} 118 \mathrm{MG}$ spheroids indicates high lactate production. High glycolysis under well oxygenated conditions as represented by the glycolytic type probably due to an impaired Pasteur effect has been described in several tumor tissues (Murray 1987) and was first indicated by Warburg (1956) as one of the major steps in

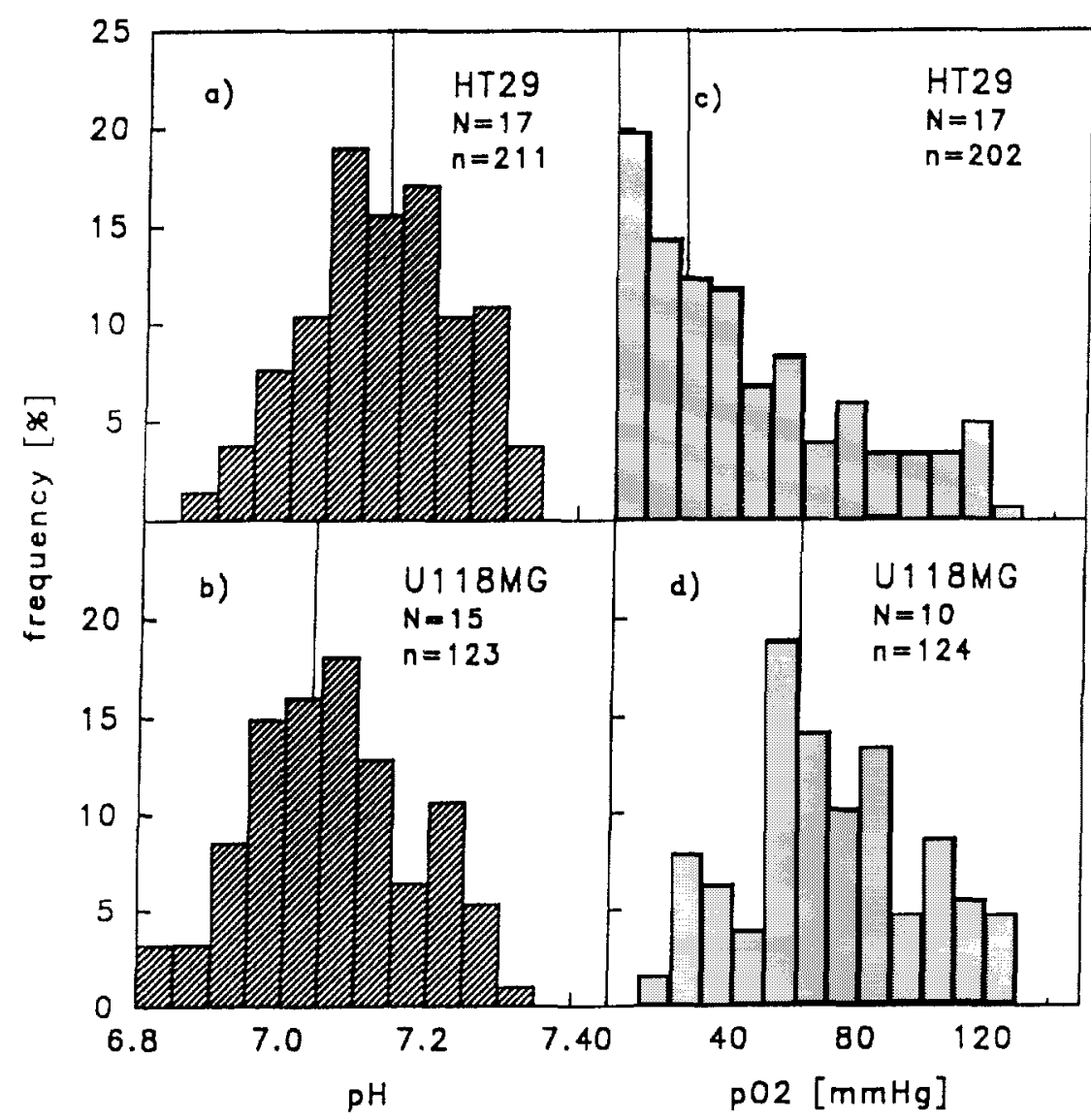

FIGURE 2 Frequence distribution of $\mathrm{pO}_{2}$ (c,d) and $\mathrm{pH}$ values (a,b) in $\mathrm{HT} 29(\mathrm{a}, \mathrm{c})$ as well as in U118MG (b,d) spheroids with a diameter between $600 \mu \mathrm{m}$ and $800 \mu \mathrm{m}$. The lines in the histograms indicate the mean values. $\mathrm{N}=$ number of MS, $n=$ number of data points. 
carcinogenesis. The initiation of glycolysis has been shown to be a major event during the $G_{0} / G_{1}-S$ progression indicating that the division cycle not only depends on mitogen mediated signals but also on conditions that maintain cellular metabolism and cell growth (Müller et al. 1993).

\section{Radiation Sensitivity (Human Cancer Cells, Oxidative and Grlycolytic Metabolism, Oxamate, $\mathrm{pO}_{2}, \mathrm{pH}$, Resistance, DNA Repair, Reactive Oxygen Species, Cell Cycle, Oncogenes)}

Radiobiological studies suggest a major influence of oxygen on radiosensitivity. In rodent tumors and probably also in human tumors hypoxic cells have been suggested to be responsible for decreased radiosensitivity. Radiobiologically significant hypoxia occurs at $\mathrm{pO}_{2}$ values below $10 \mathrm{mmHg}$ whereas the oxygen sensitizing effect is described as half maximal at about $3-4 \mathrm{mmHg}, \mathrm{pO}_{2}$ values below $10 \mathrm{mmHg}$ have been shown to correlate to increased radioresistance and radiobiological hypoxia is thought to be a major factor responsible for radioresistance of tumor cells (Sutherland 1988). Radiation resistant hypoxic cells have been demonstrated in most rodent tumors and there is evidence for their existence in human tumors. $\mathrm{pO}_{2}$ levels below $10 \mathrm{mmHg}$ have been measured in many rodent and human tumors (Vaupel et al. 1989). Different rates and extents of reoxygenation due to changes in blood flow, reduced oxygen utilisation by radiation-damaged cells or rapid cell loss with subsequent enhanced sensitization may occur during multifraction radiation treatment (Schwachhöfer 1990).

Previous publications of Görlach et al. (1995), Nylen et al. (1989), Schwachhöfer et al. (1991, 1992) however, could not reveal any clear relationship between $\mathrm{pO}_{2}$ gradients and radiation sensitivity of different human tumor cells in MS culture. HT29 spheroids with central oxygen tensions below $10 \mathrm{mmHg}$ were more radiosensitive than U118MG spheroids of comparable size with central oxygen tensions far above $10 \mathrm{mmHg}$ (Nylen et al. 1989). In NB-100 spheroids (neuroblastoma) oxygen tensions evidently showed that hypoxic cells exist, but no radiobiological hypoxia was observed. In NB-100 as well as BRO (melanoma) spheroids radiosensitivity improved to the same amount with increasing spheroid diameter in spite of completely different $\mathrm{pO}_{2}$ gradients (Schwachhöfer et al. 1992). Although no hypoxia could be detected in $\mathrm{HN}-1$ (squamous cell carcinoma) as well as in NB-100 spheroids with diameters of $200 \mu \mathrm{m},-300 \mu \mathrm{m}$, the experiments performed with spheroids of this diameter range indicate a slower repair rate of sublethal damage in the $\mathrm{HN}-1$ than in the NB-spheroids (Schwachhöfer et al. 1991). This indicates that beside oxygen availability an array of other factors might be involved in determing the degree of radiosensitivity. Reoxygenation after irradiation of hypoxic human tumor cells grown in multicellular spheroid culture (malign glioma :U118MG, U138MG, U251MG, thyroid cancer cells: Hth7, NB-100, HT29) could not be seen as $\mathrm{pO}_{2}$ - gradients measured by microelectrodes immediately after irradiation did not change in spite of a significant suppression of the number of $\mathrm{S}$ phase cells as observed in U118MG spheroids. Reoxygenation occured only after disintegration of spheroids several days after irradiation as observed in HT29 spheroids (Nylen et al. 1989, Schwachhöfer et al. 1991).

Spheroids are thought to be models for tumor cells located around blood vessels growing as cords in tumors. As radiation had no immediate effect on the oxygen tension in the spheroids these experiments may indicate that no dramatic changes in oxygen tension due to decreased oxygen utilisation of damaged tumor cells is to be expected shortly after high single dose irradiation, or early in a fractionation scheme. However, when comparisons are made with tumors in vivo, changes in oxygen tension caused by radiation-induced increase in blood flow or radiation-induced clearance of constricted blood vessels or interstitial fluid pressure (Znati et al. 1996) have to be considered, which may give rise to an increased oxygen availability. In view of the clinical significance of hypoxia in 
predicting the effectiveness of radiation treatment of tumors, the above mentioned experiments may indicate further that rather the influence of metabolic activities in tumor tissues on radioresponsiveness should be taken into account as a predictive factor for radiotherapy, than hypoxia alone.

According to a method described by Papaconstantinou and Colowick (1961), the pyruvate analogue oxamate was used in a concentration of $40 \mathrm{mM}$ to change metabolism and herewith $\mathrm{pO}_{2}$ - and pH-gradients (Görlach et al. 1995). Oxamate is a structural pyruvate analogue and known as (competitive) inhibitor of the Lactate dehydrogenase (LDH) (Nisselbaum 1964). 24 h pretreatment with the pyruvate analogue oxamate in a concentration of $40 \mathrm{mM}$ led to flatter $\mathrm{pO}_{2}$ gradients in HT29 spheroids with significantly diminished $\mathrm{pO}_{2}$ differences of $64 \mathrm{mmHg} \pm 13(p<0.01, n=10)$ and increased central $\mathrm{PO}_{2}$ values of $40 \mathrm{mmHg} \pm 16$. In U118MG spheroids no significant changes in $\mathrm{pO}_{2}$ profiles could be recorded after oxamate treatment. However, $\mathrm{pH}$ gradients were significantly flatter in these spheroids with $\mathrm{pH}$ differences of $0.12 \pm 0.01$ and central $\mathrm{pH}$ values of $7.24 \pm 0.05$ $(p<0.01, n=6)$ whereas pH gradients in HT29 spheroids were not significantly changed by oxamate. In the presence of oxamate pyruvate oxidation rates were significantly decreased in HT29 cells whereas U118MG cells showed a decreased LDH activity (Görlach et al. 1995). As oxamate is inhibiting $1-$ as well as $2-{ }^{14} \mathrm{C}$ pyruvate oxidation $\mathrm{PDH}$ activity and/or pyruvate transport into the mitochondria might be affected by this substance. This seems to be reasonable as oxamate being a structural analogue of pyruvate might occupate other binding sites of pyruvate beside LDH. In rat hepatocytes oxamate inhibited pyruvate transport into the mitochondria (Martin-Requero 1986). Whether oxamate is inhibiting pyruvate transport into the mitochondria or PDH activity in HT29 cells is not distinguishable with the methods used because decreased pyruvate transport into the mitochondria might lead to lower PDH activity as a result of impaired substrate concentration. However, both possible binding sites would impair oxidative metabolism. Thus oxamate inhibited glycolytic metabolism probably at the LDH level in U118MG spheroids and the oxidative pathway probably at the PDH or mitochondrial pyruvate transport level in HT29 spheroids.

Combining the measurements on changes of the metabolism induced by oxamate and subsequent changes of $\mathrm{PO}_{2}$ and pH-gradients in HT29 and U118MG spheroids with studies on related variations in the radiation response one might get better indications whether radiation sensitivity is mainly determined by intrinsic factors or exhibits a relationship to the $\mathrm{PO}_{2}$ and $\mathrm{pH}$ gradients in multicellular spheroids in an unknown fashion. Volume growth curves revealed an initial doubling time of $74.1 \mathrm{hrs} \pm 6.2$ for HT29 spheroids and $133.8 \mathrm{hrs} \pm 2.3$ for U118MG spheroids (Carlsson and Acker 1988, Görlach and Acker 1994, Görlach et al. 1995). In the presence of $40 \mathrm{mM}$ oxamate a growth retardation of U118MG spheroids could be observed whereas HT29 spheroids were not affected. The relative volume changes after 12 days incubation decreased significantly $(p<0.00001)$ in U118MG spheroids from $3.4 \pm 0.56$ under control conditions $(n=17)$ to $1.27 \pm 0.55(n=$ 14 ) in the presence of $40 \mathrm{mM}$ oxamate. Radiation was carried out with a daily dose rate of $5 \mathrm{~Gy}$ on $^{-8}$ consecutive days starting on day 0. HT29 spheroids with a low median $\mathrm{pO}_{2}$ were very sensitive to such experimental radiation therapy leading to complete growth inhibition and disintegration starting after 6 days. U118MG spheroids with a higher median $\mathrm{pO}_{2}$ showed no size reduction and growth was only slightly retarded with a relative volume change of $2.72 \pm 0.89$ on day 12 . Carrying out the same irradiation experiments in the presence of oxamate, however, led to complete growth inhibtion of U118MG spheroids. HT29 spheroids showed improved growth under combined therapy in comparison to irradiation under control conditions. The relative volume change on day 12 increased significantly $(p<0.001)$ from $1.08 \pm 0.17$ $(n=9)$ to $1.63 \pm 0.29(n=10)$. These results were confirmed by outgrowth tests indicating the spheroid surviving capacity as described by Carlsson and Nederman (1983). Volume growth of HT29 
spheroids was almost not affected by oxamate and outgrowth tests showed no difference to control values. Correspondingly outgrowth tests showed a decreased spheroid growth capacity by $40 \mathrm{mM}$ oxamate treatment in U118MG spheroids. Fractionated irradiation did not reduce the outgrowth in these spheroids but completely inhibited outgrowth in HT29 spheroids. Irradiations in the presence of $40 \mathrm{mM}$ oxamate, however, improved the growth capacity of HT29 spheroids to $30 \%$ whereas it was completely inhibited in the case of U118MG spheroids.

Obviously inhibition of the oxidative pathway by oxamate was not high enough to impair the growth capacity in these spheroids. In contrast, U118MG spheroids showing inhibition of the glycolytic pathway by oxamate were strongly inhibited in their proliferative capacity by oxamate as seen in both tests. However, the question remains whether growth was affected by LDH inhibition or by the concomitant $\mathrm{pH}$ shift as was described by Gillies (1981). $20 \%$ of the $\mathrm{pO}_{2}$ values have been measured below $10 \mathrm{mmHg}$ in HT29 spheroids whereas the $\mathrm{pO}_{2}$ gradients in $\mathrm{U} 118 \mathrm{MG}$ spheroids did not show $\mathrm{O}_{2}$ values below $10 \mathrm{mmHg}$. In contrast to these values HT29 spheroids exhibited a high radiosensitivity leading to volume degeneration and outgrowth inhibition whereas U118MG spheroids were growth retarded after fractionated radiation without impairment of the proliferative capacity as measured in the outgrowth test. Tissue oxygenation as result of the balance between oxygen consumption and oxygen diffusion did not correlate with the radioresponsiveness in these spheroids. Additionally, fractionated radiotherapy in the presence of oxamate improved the radiosensitivity in U118MG spheroids drastically whereas the growth inhibitory effect in HT29 spheroids was less than with experimental radiotherapy alone. Again these findings did not correlate with the oxygenation state measured by microelectrodes.

These results let suggest that neither $\mathrm{pO}_{2}$ nor $\mathrm{pH}$ gradients are correlated to variations in radiation sensitivity of HT29 or U118MG cells in multicellular spheroid culture. Determinations of the ratio $\Delta \mathrm{pO}_{2} / \Delta \mathrm{pH}$ of these spheroids, however, established a relationship to the radiation response as indicated by the relative volume change of the spheroids (Görlach et 1995). In HT29 spheroids a ratio of 381 is combined with a high radiation sensitivity whereas an oxamate induced change of the ratio to a value of 219 is related to a diminished radiation sensitivity. In U118MG spheroids a ratio of 216 corresponds to radioresistance whereas an oxamate induced change of the ratio to a value of 569 is combined with increased radiosensitivity. There seems to be the tendency that high radiation sensitivity is combined with a metabolism of the oxidative type, i.e. high values of the $\Delta \mathrm{pO}_{2} / \Delta \mathrm{pH}$ ratio, whereas radiation resistance is linked to a metabolism of the glycolytic type, i.e. low values of the $\Delta \mathrm{pO}_{2} / \Delta \mathrm{PH}$ ratio.

Radiation induced double-stranded DNA damage followed by different repair mechanisms, cell membrane damage with activation of tyrosine kinase signal pathways and ion channels or changes in the functional level of transcriptionfactors like cjun and $\mathrm{c}$-fos (AP1), p53, NFkB or the ras-encoded protein $\mathrm{p} 21$ with possible consequences for radiation resistance or radiation sensitivity have been shown to be mediated by oxygen - or hydroxyl radicals and therefore the cellular redox state (Mcllwrath et al. 1994, Miller and Samid 1995, Powell and Abraham 1993, Schieven and Ledbetter 1994 , Schultze-Osthoff et al. 1995). The amount of radicals induced by irradiation depends mainly on the oxygen level present in the tissue. However the basic level of radicals in the tissue is determined by the activity of the respiratory chain, since $5 \%$ of the mitochondrial oxygen consumption can be attributed to radical formation. We hypothezise therefore, that irradiation leads to an overload with radicals and probably to irreparable DNA damages in tumors with an oxidative $\mathrm{pO}_{2}-\mathrm{pH}$ relationship or high $\Delta \mathrm{pO}_{2} / \Delta \mathrm{pH}$ ratio as indicated in Figure 2 whereas tumor cells with a glycolytic relationship do not reach a critical level in the radical concentration due to their low level of basic radical formation. Since scavenging of hydroxyl radicals, the most harmful oxidative species, can be mediated by glucose 
oxidation only (Yu 1994), glycolytic metabolising tumor cells with a higher glucose turnover might be better protected against radiation induced DNA lesions. Clarifying the theoretical base of our model further experiments might prove the idea as the ratio of $\Delta \mathrm{pO}_{2} / \Delta \mathrm{pH}$ ratio being an useful parameter for predicting radiosensitivity of human tumor cells.

\section{Interferon (Human Malign Melanoma Cells, Human Squamous Carcinoma Cells, Interferon $\beta$, Interferon $\gamma$, Extracellular Matrix, Hypoxia, PML)}

The anti-proliferative effects of natural interferon $1 \beta($ nIFN $\beta)$ and recombinant interferon $\gamma($ rIFN $\gamma)$ on 2 human melanoma cell lines, IGR I and SKMel28, grown in monolayer and in MS culture was measured by Görlach et al. (1994a) In monolayer culture, growth of both lines was inhibited in dosedependent manner by 5-day treatments with IFN in concentrations ranging between 1 and $5,000 \mathrm{IU} / \mathrm{ml}$. Incubations with $120 \mathrm{IU} / \mathrm{ml} \operatorname{nIFN} \beta$ or $25 \mathrm{IU} / \mathrm{ml}$ rIFN $\gamma$ led to a $50 \%$ growth inhibition of IGRI cells. A $50 \%$ growth inhibition of SK-Mel28 cells was obtained with $60 \mathrm{IU} / \mathrm{ml} \operatorname{nIFN} \beta$, whereas even $5,000 \mathrm{IU} / \mathrm{ml} \mathrm{rIFN} \gamma$ inhibited the growth of this line by only $30 \%$. These results are in accordance with previous studies showing a better anti-proliferative effect of IFN $\beta$ than of IFN $\gamma$ (Johns et al., 1992; Graham et al., 1991; Garbe et al., 1990). However, SK-Mel28 cells were more resistant to rIFN $\gamma$ than in the study of Garbe et al. (1990). As the antiproliferative effects of $\mathrm{nIFN} \beta$ and $\operatorname{IIFN} \gamma$ were compared on the basis of their anti-viral activity in $\mathrm{IU} / \mathrm{ml}$ however, it is important to keep in mind that each IFN has a different anti-viral specific activity which may be independent of the anti-proliferative activity (Johns et al., 1992). Studies on the antiproliferative effects of IFN $\beta$ and IFN $\gamma$ on melanoma cells in terms of their protein concentrations, however, confirmed the higher potency of IFN $\beta$ as compared to IFN $\gamma$ (Johns et al., 1992). Removing interferon after 5 days of treatment and further cultivation with control medium resulted in a restored growth rate comparable to that of control cells after 12 or 18 days indicating a cytostatic, not cytotoxic effect of IFN and the necessity for the presence of IFN to exert growth inhibition, as also shown by others (reviewed in Clemens and McNurlan, 1985). However, cytotoxic effects after prolonged incubation with high doses of IFN $\beta$ have been described in other tumor cells after prolonged treatment (Clemens and McNurlan, 1985) despite the cytostatic nature of IFNs. This effect could only be demonstrated in tumor cells and its molecular basis is not known. Studies on solid tumors in patients often failed to achieve the high anti-proliferative effect seen in monolayer culture (Schiller et al., 1988; Abdi et al., 1988). Growing these melanoma cell lines in MS culture for 5 days reduced their sensitivity to interferon. Growth inhibition values of $50 \%$ were achieved with $3,000 \mathrm{IU} / \mathrm{ml} \mathrm{rIFN} \gamma$ or $9,000 \mathrm{IU} / \mathrm{ml} \mathrm{nIFN} \beta$ for IGRI spheroids and $10,000 \mathrm{IU} / \mathrm{ml} \mathrm{nIFN} \beta$ for SK-Mel28 spheroids, while $10,000 \mathrm{IU} / \mathrm{ml} \mathrm{rIFN} \gamma$ reduced the growth of SK-Mel28 spheroids by only $25 \%$. Outgrowth tests indicated that the proliferative capacity of these melanoma spheroids could only be reduced by high doses of $\operatorname{nIFN} \beta$ in the cell line IGR1 whereas, even in the presence of IFN during the outgrowth period, almost no reduction in proliferative capacity could be observed in SKMel28 spheroids or in IGR I spheroids treated with rIFN $\gamma$. Interferon treated MS imposed as dense nodules in tissue culture and histology demonstrated as shown in Figure 3 that, in the presence of IFN, the intercellular spaces were reduced, indicating a higher packing density. This finding suggests not only that the reduced anti-proliferative effect of $\operatorname{nIFN} \beta$ in MS as compared to monolayer cells is due to difficulties in penetration of interferon into the tissue, but also that interferon treatment led to changes in spheroid structure not observed in control spheroids. The interferon-induced reductions in volume might be at least partly due to an increased packing density rather than to direct antiproliferative effects in these melanoma spheroids. This is supported by the good survival capacity observed in the outgrowth tests as well as by the presence of mitotic figures in interferon-treated MS 

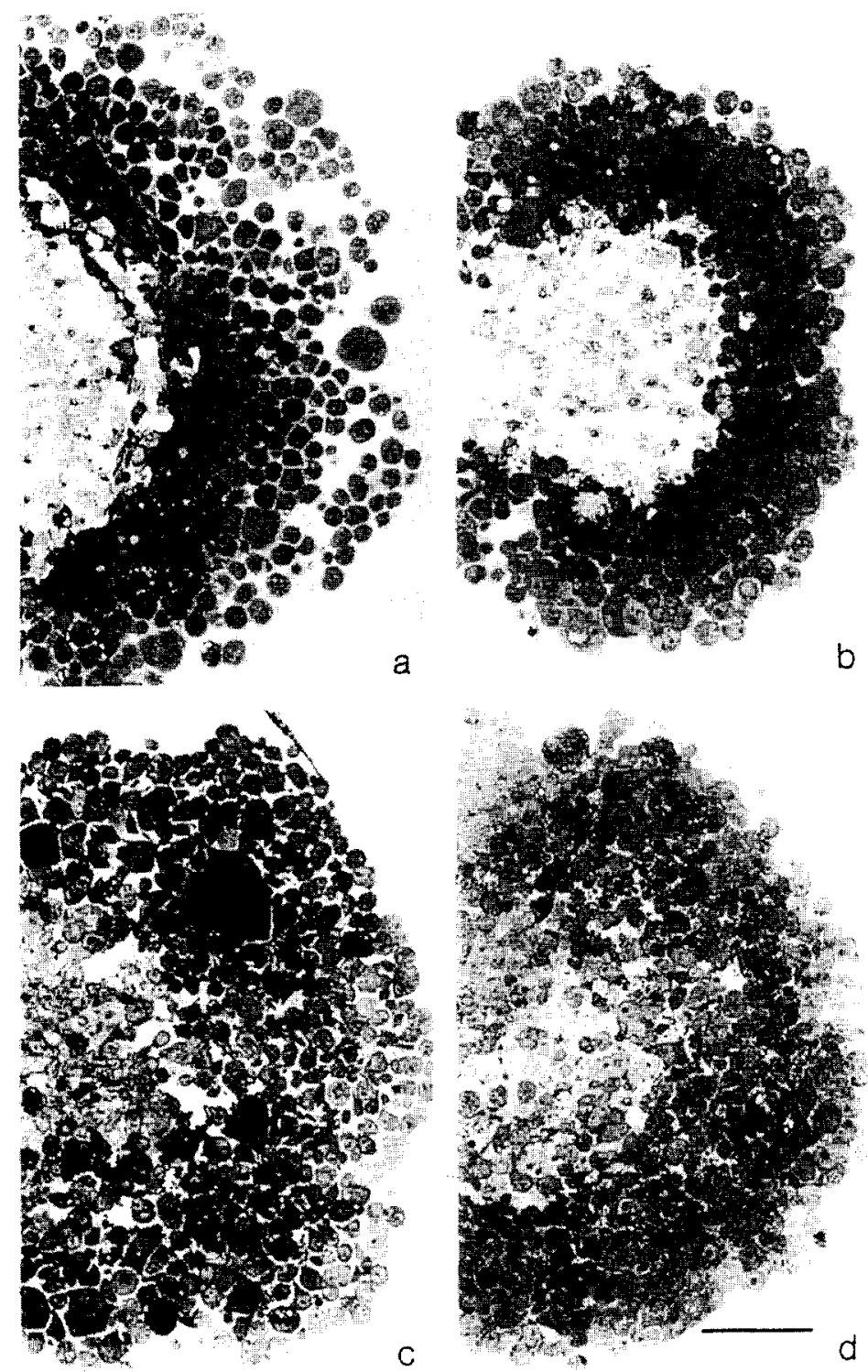

FIGURE 3 Histology of nIFN- $\Omega$-treated human in melanoma cells (IGR1, SK-Mel28) in MS culture. IGR I MS (a,b) and SK-Mel28 MS (c,d) incubated for 3 days with $1000 \mathrm{IU} / \mathrm{ml}$ nIFN $\beta$ (b,d) exhibited a denser viable rim with reduced intercellular space. Thus, the volume reductions observed in these MS by nIFN $\beta$ treatments might be, at least in part, due to an increased packing density rather to direct growth inhibition $(\mathrm{Bar}=100 \mu \mathrm{m})$. (Görlach et al. 1994).

(Görlach et al. 1994a). Thus the volume reductions of melanoma MS observed after IFN treatment might be due rather to the increased packing density than to direct anti-proliferative effects. Scanning elecron microscopy furthermore showed variations on the surface IFN-treated spheroids as well as in cellular organization and structures between cells, hinting at a possible involvement of extracellular matrix substances in the reaction to interferons. These findings show that the high anti-proliferative sensitivity of the melanoma cell lines in monolayer culture could not be achieved in MS mirroring the situations in patients (Görlach et al. 1994a). The same observation has been published by Sacks 
et al. (1994) with a higher resistance of squamous carcinoma cells in MS culture than in monolayer culture to $\operatorname{IFN} \beta$ and $\gamma$ induced growth inhibition. This phenomenon could be explained for example by a decreased antiproliferative effect of IFN due to hypoxic regions in MS (Naldini et al. 1995) or abnormalities in structure, localisation or expression of the nuclear matrix PML protein (Pro-Myelocytic Leukaemia) which is a primary target gene of IFNs and suited to mediate some of their antiproliferative effects (Stadler et al. 1995).

\section{Doxorubicin (Human Malign Prostate Cells, Diffusion, Storage, Reactive Oxygen Species, Oncogenes)}

Different tumor cell lines vary in their sensitivity and resistance to particular chemotherapeutic agents (Liminga et al. 1994). On the other hand tumor cells may exhibit different sensitivities to chemotherapy depending on their location within the three dimensional tumor tissue (Olive and Durand 1994). Many investigators have described patterns of drug resistance in MS (Kobayashi et al. 1993, Erlichmann and Vidgen 1984, Kwok and Twentymann 1985, Erlanson et al. 1992, Inoue et al. 1987, West and Stratford 1987). Any occurrance of tumor cell resistance during drug application results in a failure of cancer chemotherapy due to surviving cells. Therefore finding a way to circumvent multi-drug resistance is a major challenge in oncology. The reason for the patterns of drug sensitivity in different cell layers of MS is not yet clear. Two problems are still in the focus of discussion: a) The limited diffusion capacity of the drug in the MS and b) Uptake and accumulation in the cells, versus outward diffusion and transport by membrane transport systems (Olive and Durand 1994). Wartenberg and Acker (1996a) studied the effects of the quinone containing and reactive oxygen species producing anticancer drug Doxorubicin (Dox) on necrosis development and cell lethality of the human malign prostate cancer cell line DU-145 in MS culture. After the application of Dox for different time periods dead areas and single dead cells in MS of different size classes were identified using a set of lethal fluorescence dyes (LYVS, Ethidium homodimer 1) and CLSM. The distribution of within MS was examined by determining Dox fluorescence in single cells and cell areas. The application of low $(400 \mathrm{nM})$ concentrations of Dox over a time period of $2 \mathrm{hrs}$ resulted in distinct Dox fluorescence staining of the most peripheral cell layers of the MS. After long term incubation (48 hrs) cell lethality was most prominent in large spheroids (diameter between $350 \mu \mathrm{m}$ and $800 \mu \mathrm{m}$ ) which possess a dead cell core and single dead cells at the periphery. These MS showed an approximately $120 \mu \mathrm{m} \pm 30$ increased dead cell core as compared to control MS. The cytotoxic effect of Dox on cell growth was lower in MS of a diameter between $150-350 \mu \mathrm{m}$ than in MS with a diameter $>350 \mu \mathrm{m}$ and nearly no cytotoxic effects were found in spheroids smaller than $150 \mu \mathrm{m}$ in diameter (Figure 4). Dox fluorescence persisted in dead cells of larger MS at least three days. During this time the cytotoxic agent leaked slowly from dead cells and penetrated into the layers of quiescent cells and proliferating cells mediating a prolonged cytotoxity as shown in Figure 4. It has been described by Miller and Samid (1995) that the amount of ras-encoded protein 21 produced and its membrane localization appeared to be critical for maintenance of cellular resistance to Dox mediated production of reactive oxygen species. This effect might be additionally involved in the varying resistance of DU-145 MS of different diameter as shown in Figure 4.

\section{Oxygen Dependent Gene Expression (Oxygen Sensing, NADPH Oxidase, Reactive Oxygen Species, Angiogenesis, Cell Growth, Cell Death, Transcription Factors, Oncogenes, Gene Therapy)}

MS have been shown to be a good model for studying hypoxic upregulation of vascular endothelial growth factor gene expression (Waleh et al. 1995, Schweiki et al. 1995). The knowledge of the molecular mechanism involved in this oxygen dependent gene expression might be important to design new strategies for suppressing tumor angiogenesis. An appropriate strategy might be gene therapy which 


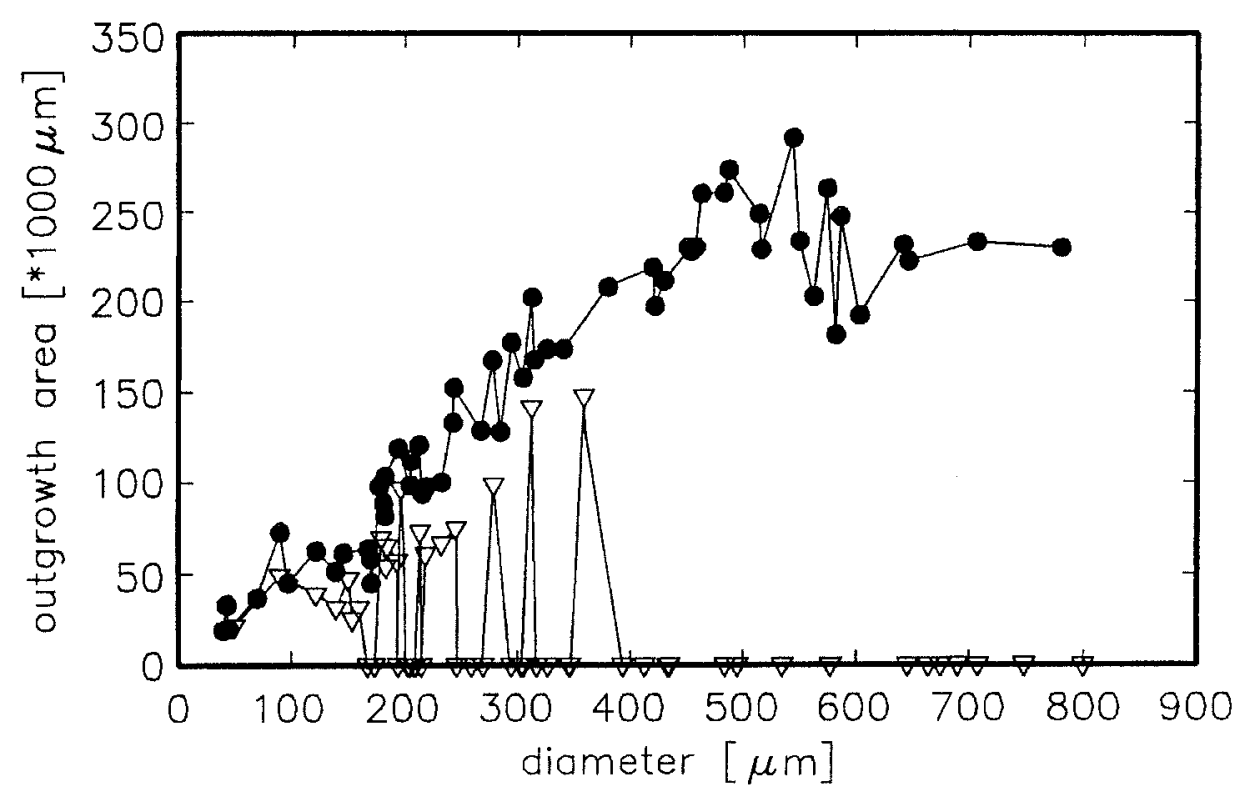

FIGURE 4 Outgrowth area of DU 145 control MS (filled circles) and Dox treated MS ( $400 \mathrm{nM}, 48$ hrs) (hollow triangles) due to MS diameter. The outgrowth area was calculated after $\mathrm{DiOC}_{6}$ staining of the outgrowing cells using the software facilities of the confocal laser scanning microscope (Wartenberg and Acker 1996a).

was already successfully applied on human lung cancer MS to induce apoptosis by transduction of cells by a wild type p53 retroviral vector (Fujiwara et al. 1993).

To assert a constant oxygen supply to different organs and herewith a constant energy supply maintaining highly specialized organ functions, cells able to sense oxygen levels in the tissue are situated at different locations in the body stimulating various reflex pathways. This oxygen sensing process comprises a sensor protein which undergoes conformational changes in dependence on oxygen and a signal cascade, which transfers the message stimulated by the sensor to metabolic pathways or specific gene regions (for review see Acker 1994). For the last pathway numerous example are given in the literature like the $\mathrm{CoCl}_{2}$ impedible induction of phosphoenolpyruvate carboxykinase (PCK) by glucagon in hepatocytes (Kietzmann et al. 1992), the regulation of the glutathion peroxidase content in cardiomyocytes (Cowan et al. 1993), the gene expression for tyrosin hydroxylase in carotid body type I - and PC12 - cells (Czykzyk-Krzeska et al. 1994), the regulation of the bovine endothelial constitutive nitric oxide synthase (Liao et al. 1995) or the production of erythropoietin, vascular endothelial growth factor, plateletderived growth factor A and B chains, placental growth factor and transforming growth factor in various cell lines (Gleadle et al. 1995, Goldberg et al. 1994). Metabolic pathways comprise the lactate dehydrogenase activity (Marti et al. 1994), the mitochondrial manganese-containing superoxide dismutase activity (MnSOD) of the lung (Russel et al. 1995 ) or the pregnenolone and aldosterone synthesis (Raff and Jankowski 1995). The oxygen level in the tissue of different organs is determined by the oxygen partial pressure and the $\mathrm{O}_{2}$ transport capacity of the blood as well as by the vascular structure, blood flow, oxygen consumption and diffusion conditions of each particular organ. Characteristically the different organs have a frequency distribution of oxygen partial pressure values ranging from about $0 \mathrm{mmHg}$ to $100 \mathrm{mmHg}$ with mean values between $20 \mathrm{mmHg}$ and $50 \mathrm{mmHg}$ (Acker 1994). While in former times the meaning of this $\mathrm{pO}_{2}$ distribution was mainly discussed for its importance for energy supply under normoxic and hypoxic conditions, it 
is obvious now that the $\mathrm{pO}_{2}$ distribution expresses the different oxygen sensitivities of the above mentioned ion channels, metabolic pathway activities and gene regions. Low as well as high $\mathrm{pO}_{2}$ values have distinct influences. Low $\mathrm{pO}_{2}$ is accompanied by an enhanced production of erythropoietin. vascular endothelial growth factor platelet-derived growth factor A and B chains, placental growth factor and transforming growth factor (Gleadle et al. 1995, Goldberg et al. 1994), or tyrosine hydroxylase (TH) (Czykzyk-Krezeska et al. 1994) peaking between $1 \%$ and $3 \% \quad \mathrm{O}_{2}$ whereas high $\mathrm{PO}_{2}$ incites a higher production of glutathione peroxidase (Cowan et al. 1993) or of phosphoenolpyruvate carboxikinase (Kietzmann et al. 1992) and an enhanced activity of the endothelial constitutive nitric oxide synthase (Lioa et al. 1995). Lactate dehydrogenase activity is increased (Marti et al. 1994) whereas MnSOD activity is decreased under low oxygen levels (Russels et al. 1995). In contrast pregnenolone and aldosterone synthesis is enhanced under high oxygen levels (Raff and Jankowski 1995). Whereas the oxygen responsive elements of the genes encoding the different proteins have been partly identified (Cowan et al. 1993, Gleadle et al. 1995, Goldberg et al. 1994) the nature of the oxygen sensing protein influencing metabolic pathway activities and gene expression is still unclear in mammalian cells. However studies on bacteria could described signal cascades influencing gene expression under hypoxic as well as hyperoxic conditions. Activation of the nitrogen fixation gene in Rhizobium meliloti under hypoxia is mediated by a cell membrane located heme-based sensor which phosphorylates a transcription factor for facilitating its DNA binding (Gilles-Gonzalez and Gonzalez 1993). Escherichia coli contains the SoxR protein, which activated by oxidative stress like hyperoxia through a variable redox state of its FeS cluster induces transcription of the SoxS gene, which in turn increases expression of defensive genes such as Mn-containing superoxide dismutase (Hildago and Demple 1994). It has been shown by Görlach et al. (1994) using spectrophotometry and western blot analysis that hypoxia induced Epo production of human liver cancer HepG2 cells in MS culture is mediated by a non respiratory heme protein as an oxygen sensor. This heme protein is capable of $\mathrm{H}_{2} \mathrm{O}_{2}$ formation and seems to possess similarities with flavocytochrome $b_{558}$ of the NADPH oxidase in neutrophils with p22 2 phox , gp $91_{\text {phox }}, \mathrm{p} 47_{\text {phox }}$ and $\mathrm{p} 67_{\text {phox }}$ as typical components (Bokoch 1993). The oxidase has a declining $\mathrm{H}_{2} \mathrm{O}_{2}$ formation in HepG2 cells under hypoxia which might due to a changed redox. state of the cells promoting the binding of transcription factors like HIF to the oxygen responsive element of the Epo gene (Fandrey et al. 1994). Gleadle et al. (1995a) underlined the importance of a flavoprotein oxidoreductase as an oxygen sensor by inhibiting the hypoxia induced gene expression of five genes by means of diphenylene iodonium an inhibitor of the neutrophile NAD(P)H oxidase. This oxidase might be termed according to Bastian and Hibbs (1994) as low output form with respect to the rate of $\mathrm{H}_{2} \mathrm{O}_{2}$ production. This is in contrast to the stimulusdependent respiratory burst-like activity of the high out put oxidase in leucocyte defense mechanisms having an about $95 \%$ higher production rate than the low output form (Jones et al. 1995). In case of the hyperoxia induced aldosterone production the oxygen sensitive side is likely to be located in the mitochondrial aldosterone synthase enzyme complex (Raff and Jankowski 1995). A heme-protein seems to be not involved in this oxygen sensing process.

The meaning of oxygen sensors for tumor cells might be seen in their influence on the cellular redox state and herewith folding of proteins, receptor assembly and transcription factor activity by producing reactive oxygen species in dependence on $\mathrm{PO}_{2}$ which are scanvenged by systems like glutathion, thioredoxin or catalase (Powell and Abraham 1993). Transcription factor like HIF, p53, Waf1/Cip1, AP1, NFkB or the stability of rasmRNA which have been shown to be involved in the regulation of angiogenesis, cell growth and death or drug and radiation sensitivity are controlled in their activity by this mechanism (Gleadle et al. 1995, Goldberg et al. 1994, Miller et al. 1993, Graeber et al. 1996, Powis et al. 1995, Russo et al. 1995). Oxygen sensors with different rates of reactive oxygen 
species production at different spots in the $\mathrm{pO}_{2}$ field of a tumor might be therefore a possible target for future cancer therapies.

\section{CONCLUSION}

The aim of the article was to show with the aid of the multicellular spheroid model recent findings on the heterogeneous interaction between microenvironment and therapy in tumors which might be stimulatory for clinicians, biologists and mathematicians to design and improve, in a concerted action, therapeutic strategies for tumor patients. Two new technical developments might improve the impact of the proposed action: 1. cultivation of individual tumor biopsy material in multicellular spheroid culture (Fjellbirkeland et al. 1995) and 2. the detection of fluorescent probes specific for various tumor cells activities non invasively in different depths of the spheroids by confocal laser microscopy combined with multiphoton excitation for mapping with a subsequent threedimensional reconstruction the heterogeneity of the tumor cell response to the various therapeutic modalities (Porwol et al. 1996).

\section{References}

Abdi, E. A., Tan, Y. H. and McPherson, T. A. (1988) Natural human interferon-beta in metastatic malignant melanoma. A phase II study. Acta Oncol., 27, 815-817.

Acker, H. (1994) Mechanisms and meaning of cellular oxygen sensing in the organism. Resp. Physiol., 95, 1-10.

Acker, H., Carlsson, J., Durand, R. and Sutherland, R.M. (1984) Spheroids in Cancer Research, Recent Results in Cancer Research, 95, 1-179.

Bastian, N. R. and Jr. Hibbs, J. B. (1994) Assembly and regulation of NADPH oxidase and nitric oxide synthase. Current Opinion Immunol, 6, 131-139.

Bauer, K. D., Keng, P. C. and Sutherland, R. M. (1982) Isolation of quiescent cells from multicellular tumor spheroids using centrifugal elutriation Cancer Res., (1987), 42, 72-78.

Bokoch, G. M. (1993) Biology of the Rap proteins, members of the ras superfamily of GTP-binding proteins. Biochem J., 289 17-24.

Bjerkvig, R. (1982) Spheroid culture in Cancer Research, CRC Press.

Carlsson, J. and Acker, H. (1988) Relations between pH, oxygen partial pressure and growth in cultured cell spheroids. Int. J. Canc., 42, 715-720.

Carlsson, J. and Nederman, T. (1983) A method to measure the radio and chemosensitivity of human spheroids. Adv. Exp. Med. Biol., 159, 399-417.
Clemens, M. J. and McNurlan, M. A. (1985) Regulation of cell proliferation and differentiation by interferons. Biochem $\mathrm{J}$, 282, 346-360.

Cowan, D. B. Weisel, R. D. Williams, W. G. and Mickle, D. A. G. (1993) Identification of oxygen responsive elements in the 5'flanking region of the human gluthation peroxidase gene. J. Biol. Chem., 268, 26904-26910.

Czykzyk-Krzeska, M., Furnari, B. A., Lawson, E. E. and Millhorn, D. E. (1994) Hypoxia increases rate of transcription and stability of tyrosine hydroxylase mRNA in pheochromocytoma (PCl2) cells. J. Biol. Chem., 7, 760-764.

Dichiro, G., Hatazawa, J., Katz, D. A., Rizzoli, H. V. and Demichele, D. J. (1987). Glucose utilization by intracranial meningeomas as an index of tumor aggressivity and probability of recurrence: a PET study. Radiology, 164, 521-526.

Durand, R. E. (1990) Multicell spheroids as a model for cell kinetic studies Cell Tissue Kinet., 23, 141-159.

Erlichmann, C. and Vidgen, D. (1984) Cytotoxity of doxorubicin in MGH-U1 cells grown in monolayer cultures, spheroids and xenografts in imune-deprived mice. Cancer Res., 44 , $5469-5475$.

Erlanson, M., Daniel-Szolgay, E. and Carlsson, J. (1992) Relations between the penetration, binding and average concentration of cytostatic drugs in human tumor spheroids Cancer Chemother Pharmacol, 29, 343-353.

Fandrey, J., Frede, S. and Jelkmann, W. (1994) Role of hydrogen-peroxide in hypoxia-induced erythropoietin production. Biochem J, 303, 507-510.

Fjellbirkeland, L., Bjerkvig, R. and Laerum, O. D. (1995) Tumor fragment spheroids from human non-small-cell lung-cancer maintained in organculture. Virchows Archiv-An International Journal of Pathology, 426, 169-178.

Fujiwara, T., Grimm, E. A., Mukhopadhaya, T., Cai, D. W., Owen-Schaub, L. B. and Roth, J. A. (1993) A retroviral wildtype p53 expression vector penetrates human lung cancer spheroids and inhibits growth by inducing apoptosis. Cancer Res., 53, 4129-4133.

Garbe, C.. Krasagakis, K.. Zouboulis, C. Z., Schröder, K., Krüger, S., Stadler, R. and Orfanos, C. E. (1990) Antitumor activities of interferon alpha, beta and gamma and theri combinations on human melanoma cells in vitro: changes of proliferation, melanin synthesis and immunophenotype. J. invets. Dermatol., 95, 231S-237S

Gilies, R. J. (1981) Intracellular $\mathrm{pH}$ and growth control in eukaryotic cells. In The Transformed Cell (I. L. Cameron and T. B. Pool Eds.), Academic, New York-London, pp. 347-395.

Gilles-Gonzalez, M. A and Gonzalez, G. (1993) Regulation of the kinase activity of heme protein FixL from the twocomponent system FixL/FixJ of Rhizobium meliloti. J Biol Chem, 268, 16293-16297.

Gleadle, J. M., Ebert, B. L., Firth, J. D. and Ratcliffe, P. J. (1995) Regulation of angiogenic growth factor expression by hypoxia, transition metals and chelating agents. Am J Physiol, 268, C1362-C1368

Gleadle, J. M., Ebert, B. L. and Ratcliffe, P. J. (1995a) Diphenylene iodonium inhibits the induction of erythropoietin and other mammalian genes by hypoxia-implications for the mechansim of oxygen sensing. Eur J Biochem, 234, $92-99$.

Goldberg, M. A. and Th. Schneider, J. (1994) Similarities between the oxygen sensing mechanisms regulating the expression of vascular endothelial growth factor and erythropoietin. J. Biol. Chem., 269, 4355-4359.

Görlach, A., Bölling, B., Holtermann, G., Schwachöfer, J., CarIsson, J. and Acker, H. (1995) Changes in growth, $\mathrm{pO}_{2}$ and $\mathrm{pH}$ after exposure to oxamate: studies of two human tumour 
cell lines growing as multicellular spheroids Int. J. Oncol., 7, $831-839$.

Görlach, A. and Acker, H. (1994) $\mathrm{pO}_{2}$ - and pH-gradients in multicellular spheroids and their relationship to cellular metabolism and radiation sensitivity of malignant human tumor cells BBA, 1227, 105-112.

Görlach, A., Herter, P.. Hentschel, H., Frosch, P. J. and Acker, H (1994a) Effects of nIFN $\beta$ and rIFN $\gamma$ on growth and morphology of two human melanoma cell lines: comparison between two - and three-dimensional culture. Int $\mathrm{J}$ Cancer 56, 249-254

Görlach, A., Holtermann. G., Jellkmann, W.. Hancock, J. T., Jones, S. A., Jones, O. T. G. and Acker, H. (1993) Photometric characteristics of haem proteins in erythropoietin producing hepatoma cells (HepG2). Biochem. J., 290, 771-776.

Graham, G. M., Guarini, L., Moulton, T. A., Datta, S., Ferrone, S., Giacomini, P., Kerbel, R. S. and Fisher, P. B. (1991) Potentiation of growth suppression and modulation of the antigenic phenotype in human melanoma cells by combination of recombinant human and immune interferons. Cancer Immunol. Immunother., 32, 382-390.

Graeber, T. G., Osmanian, C., Jacks, T.. Housman, D. E., Koch. C. J., Lowe, S. W. and Giaccia, A. J. (1996) Hypoxia mediated selection of cells with diminished apoptotic potential in solid tumors. Nature, 379, 88-91.

Hidalgo, E. and Demple, B. (1994) An iron-sulfur center essential for transcriptional activation by the redox-sensing SoxR protein. EMBO, 13, 138-146.

Haji-Karim, M. and Carlsson, J. (1978) Proliferation and viability in cellular spheroids of human origin. Cancer Res., 38 $1457-1464$.

Inoue, S. Ohuma, T. Takaoka, K. Suzuki, Y., Kaneko, M., Safirstein, R. and Holland, J. F. (1987) Effects of doxorubicin and cisplatin on multicellular tumor spheroids from human lung cancer. Cancer Drug Del 4, 213-224.

Johns, T. G., Mackay, I. R., Callister, K. A., Hertzog, P. J. Devenish, R. J. and Linnane, A. W. (1992) Antiproliferative potencies of interferons on melanoma cell lines and xenografts: higher efficacy of interferon $\Omega$ J. Nat. Cancer Inst., 84. 1185- 1190 .

Jones, O. T. G., Jones, S. A. and Wood, J. D. (1995) Expression of components of the superoxide generating $\mathrm{NAD}(\mathrm{P}) \mathrm{H}$ oxidase by human leucocytes and other cells. Protoplasma, 184, 79-85.

Kobayashi, H., Man, S., Graham, C. H., Kapitain, S. J., Taicher, B. A. and Kerbel, R. S. (1993) Aquired multicellular mediated resistance to alkylating agents in cancer. PNAS, 90 3294-3298.

Th. Kietzmann, Schmidt, H., Probst, I. and Jungermann, K. (1992) Modulation of the glucagon-dependent activation of the phosphoenolpyruvate carboxykinase gene by oxygen in rat hepatocyte cultures FEBS Lett., 311(3), 251-255.

Kwok, T. T. and Twentymann, P. R. (1985) The relationship between tumour geometry and the response of tumour cells to cytotoxic drugs - an in vitro study using EMT6 multicellular spheroids. Int J Cancer, 35, 675-682.

Lioa, J. K., Zulueta, J. J., Yu, F. Sh., Peng, H. B., Cote, C. G and Hassoun, P. M. (1995) Regulation of bovine endothelia constitutive nitric oxide synthase by oxygen. J. Clin. Invets., 96. $266 \mathrm{I}-2666$

Liminga, G., Nygren, P. and Larsson, R. (1994) Microfluorometric evaluation of calcein acetoxymethyl ester as a probe for P-glycoprotein-mediated resistance: effects of Cyclosporin A and its nonimmunosuppressive analogue SDZ PSC 833 Exp. Cell. Res., 212, 291-296.

Marti, H. H., Jung, H. H., Pfeilschifter, J, and Bauer, C. (1994) Hypoxia and cobalt stimulate lactate dehydrogenase (LDH) activity in vascular smooth muscle cells. Pflügers Arch, 429, $216-222$.

Martin-Requero, A., Ayuso, M. S. and Parrilla, R. (1986) Interaction of oxamate with the gluconeogenetic pathway in rat liver. Arch. Biochem. Biophys., 246, 114-127.

Mcllwrath A Vasey, P. A Ross, G. M and Brown, R (1994) Cell cycle arrests and radiosensitivity of muan tumor cell lines: dependence on wild-type p53 for radiosensitivity. Cancer Res. $\mathbf{5 4}, 3718-3722$.

Miller, A. C. and Samid. D. (1995) Tumor resistance to oxidative stress: association with ras oncogene expression and reversal by lovastatin, and inhibitors of $\mathrm{p} 21_{\mathrm{ras}}$ isoprenylation. Int. J. Cancer, 60. 249-254

Miller, A. C., Gafner, J,, Clark, E. P. and Samid, D. (1993) Posttranscriptional down-regulation of ras oncogene expression by inhibitors of cellular glutathione. Mol Cell Biol, 13(7), 4416-4422.

Murray, R. K. (1987) Biochemical properties of cancer cells. In The Basic Science of Oncology (I. F. Tannock and R. P. Hill, Eds.), Pergamon, Elmsford NY, pp. 176-191.

Müller, R., Mumberg, D. and Lucibello, F. C. (1993) Signals and genes in the control of cell-cycle progression. BBA, 1155, $151-179$.

Müller-Klieser, W. (1987) Multicellular spheroids, a review on cellular aggregates in cancer research. J. Cancer Res Clin Oncol, 113, 101-122.

Naldini, A., Carraro, F. and Bocci, V. (1995) Effects of hypoxia on the antiproliferative activity of human interferons $\mathbf{J}$ Interf Cyt Res, 15. 137-142.

Nisselbaum, J. S., Packer, D. E. and Bodansky, O. (1964) Comparison of the actions of human brain, liver, and heart lactic dehydrogenase variants on nucleotide analogues and on substrate analogues in the absence and in the presence of oxalate and oxamate. J. Biol. Chem., 239, 2830-2834.

Neyfakh, A. A. (1988) Use of fluorescent dyes as molecular probes for the study of multidrug resistance Exp. Cell. Res. $174,168-176$.

Nylen, T., Acker, $H$, Bölling, B. Holtermann, G. and Carlsson, J. (1989) Influence of ionizing radiation on oxygen profiles in different types of multicellular spheroids. Radiation Res.. 120, 213-226.

Olive, P. and Durand, R. E. (1994) Drug and radiation resistance in spheroids: cell contact and kinetics. Cancer Metast. Rev. $13,121-138$

Papaconstantinou, J. and Colowick, S. P. (1961) The role of glycolysis in the growth of tumor cells. J. Biol. Chem., 236, $276-292$.

Porwol, T., Merten, E. Opitz, N and Acker, H. (1996) 3D Imaging of Rhodamine 123 Fluorescence Distribution in Human Melanoma Cells by Means of Confocal Laser Scanning Microscopy Acta Anatomica, 157, 116-125.

Powell, S. P. and Abraham, E. H. (1993) The biology of radioresistance: similarities, differences and interactions with drug resistance. Cytotechnol., 12, 325-345.

Powis, G., Briehl, M. and Oblong. J. (1995) Redox signalling and the control of cell growth and death. Pharmac. Ther. 68(1), 149-173.

Raff, H. and Jankowski, B. (1995) $\mathrm{O}_{2}$ dependence of pregnenolone and aldosterone synthesis in mitochondria from bovine zona glomerulosa cells. J. Appl. Physiol, 78(5): $1625-1628$.

Russel, W. J., Ho, Y. S., Parish, G. and Jackson, R. M. (1995) Effects of hypoxia on MnSOD expression in mouse lung Am. J. Physiol, L221-L226.

Russo, T.,Zambrano, N.,Eposito, F. Ammendola, R., Cimino, F., Fiscella, M., Jackmann, J., O'Conner, P. M., Anderson, C. W. 
and Appella, E. (1995) A p53-independent pathway for activation of WAF1/CIP1 expression following oxidative stress. J Biol Chem, 270(49), 29386-29391.

Sacks, P. G., Racz, T., St. Schantz, P. and Rosenblum, M. G. (1994) Growth inhibition by interferon beta and gamma of MDA 886Ln monolayer cells and multicellular spheroids. Arch Otolaryngol Head Neck Surg. 120, 1267-1272.

Schiller, J. H., Stober, B., Bittner, G., Willson, J. K. V. and Boden, E. C. (1988) Phase II trial of a combination of Interferon- $\Omega_{\mathrm{ser}}$ and interferon- $\eta_{0}$ in patients with advanced malignant melanoma. J. Inteferon Res., 8, 581-589.

Schieven, G. L. and Ledbetter, J. A. (1994) Activation of tyrosine kinase signal pathways by radiation and oxidative stress. TEM, 5(9), 383-388.

Schultz-Osthoff, K., Ios, M. and Baeuerle, P. A. (1995) Redox signalling by transcription factors like NFkB and AP-1 in lymphocytes. Biochem. Pharmakol., 50(6), 735-741.

Schwachhöfer, J. H. M. (1990) Multicellular tumor spheroids in radiotherapy research (review). Anticancer Res, 10, 963-970.

Schwachöfer, J. H. M. Acker, H. Croojmans, R. P. M. A., Holtermann, G., Hoogenhout, J., Kal, H. B. and Theeuwes, A. G. M. (1992) Radiosensitivity of spheroids from two human tumour cell lines in relation to oxygen tension and oxygen consumption. Cancer Res., Therapy and Control, $\mathbf{3}$, $7-14$.

Schwachöfer, J. H. M., Acker, H., Croojmans, R. P. M. A., Van Gasteren, J. J. M., Holtermann, G., Hoogenhout, J., Jerusalem, C. R. and Kal, H. B. (1991) Oxygen tensions in two human tumour cell lines grown and irradiated as multicellular sheroids. Anticancer Res., 11, 273-280.

Shweiki, D., Neeman, M., Itin, A. and Keshet, E. (1995) Induction of vascular endothelial growth factor expression by hypoxia and by glucose deficiency in multicell spheroids: Implications for tumor angiogenesis. PNAS, 92, 768-772.

Stadler, M., Chelbi-Alix, M. K., Koken, M. H. M., Venturini, L., Lee, C., Saib, A., Quignon, F., Pelicano, L., Guillemin, M. C.,
Ch. Schindler, and de Thé, H. (1995) Transcriptional induction of the PML growth growth suppressor gene by interferons is mediated through an ISRE and a GAS element. Oncogene, 11 2565-2573.

Sutherland, R. M. (1988) Cell and environment interactions in tumor microregions: The multicell spheroid model. Science, 240, $177-184$

Sutherland, R. M., Rasey, J. S. and Hill, R. P. (1988) Tumor biology. Am. J. Clin. Oncol. (CCT), 11, 253-274.

Vaupel, P. W., Kallinowski, F. and Okunieff, P. (1989) Blood flow, oxygen and nutrient supply and metabolic microenvironment of human tumors: a review. Cancer Res, 49, 6449-6465. Waleh, N. S., Brody, M. D., Knapp, M. A., Mendonca, L., Lord E. M. Koch, C. J., Landeroute, K. R. and Sutherland, R. M. (1995) Mapping of vascular endothelial growth factor-producing hypoxic cells in multicellular tumor spheroids using a hypoxia-specific marker. Cancer Res, 55, 6222-6226.

Warburg, O. (1956) On the origin of cancer cells. Science, 123, $309-314$.

Wartenberg, M. and Acker, H. (1996) Quantitative recording of vitality patterns in living multicellular spheroids by confocal miccroscopy. Micron, 26(5), 395-404.

Wartenberg, M. and Acker, H. (1996a) Doxorubicin effects on necrosis development in multicellular spheroids as studied by confocal laser scanning microscopy. Anticancer Res, 16(2), 573-580.

West, C. M. L. and Stratford, I. J. (1987) A comparison of doxorubicin and m-AMSA. II. Studies with V79 and human tumour multicellular spheroids. Cancer Chemother. pharmacol, 20, 109-114.

Yu, B. P. (1994) Cellular defenses against damage from reactive oxygen species. Physiol. Rev., 74(1), 139-162.

Znati, C. A., Rosenstein, M., Boucher, Y., Epperly, M. W. Bloomer, W. D. and Jain, R. K. (1996) Effect of radiation on interstitial fluid pressure and oxygenation in a human tumor xenograft. Cancer Res., 56(5), 964-968. 


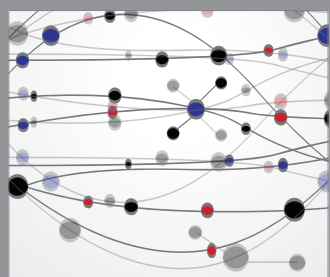

The Scientific World Journal
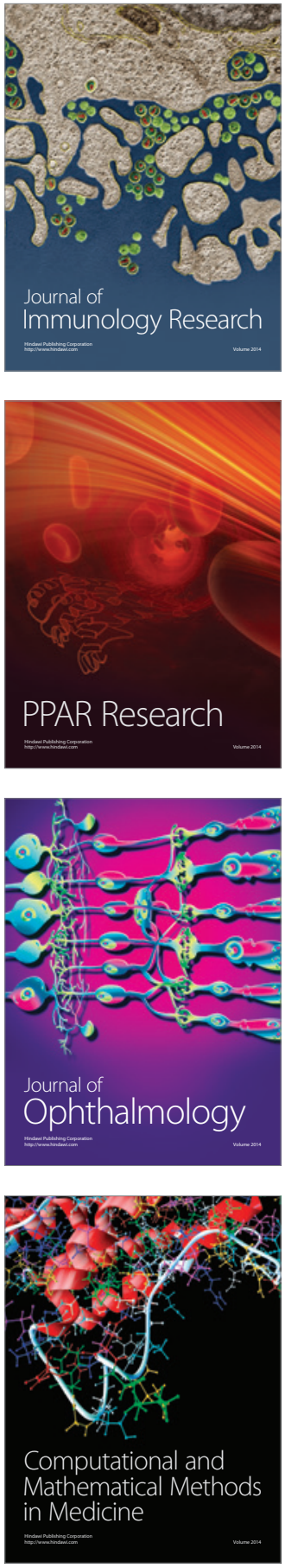

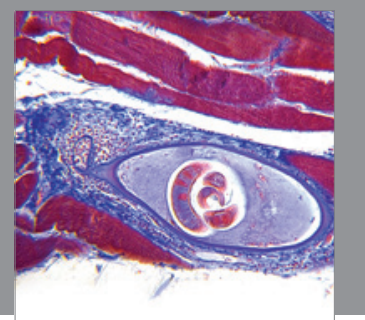

Gastroenterology

Research and Practice
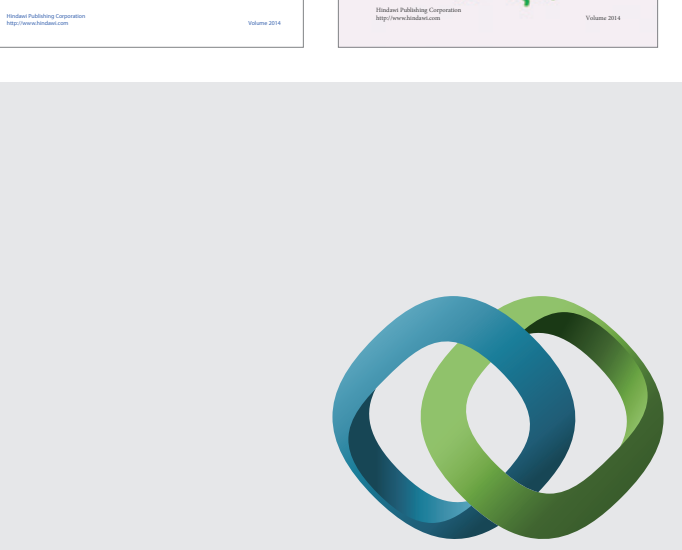

\section{Hindawi}

Submit your manuscripts at

http://www.hindawi.com
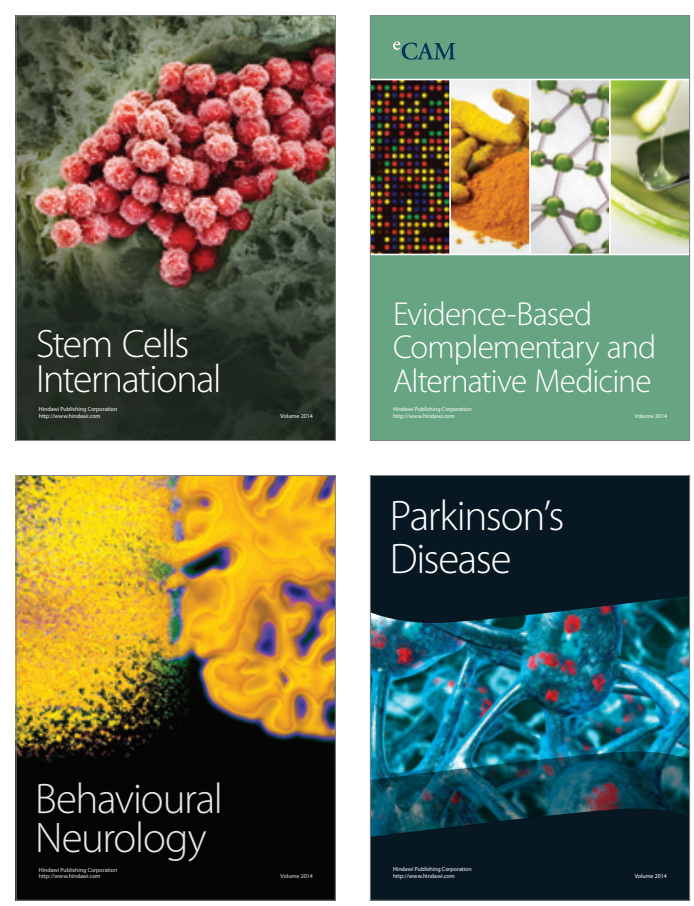

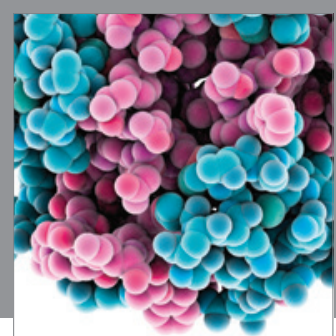

Journal of
Diabetes Research

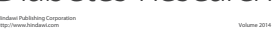

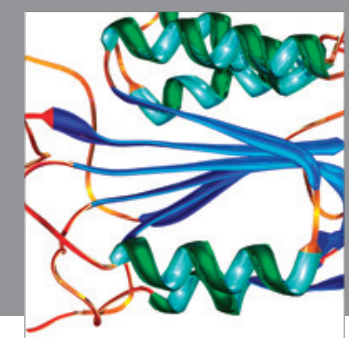

Disease Markers
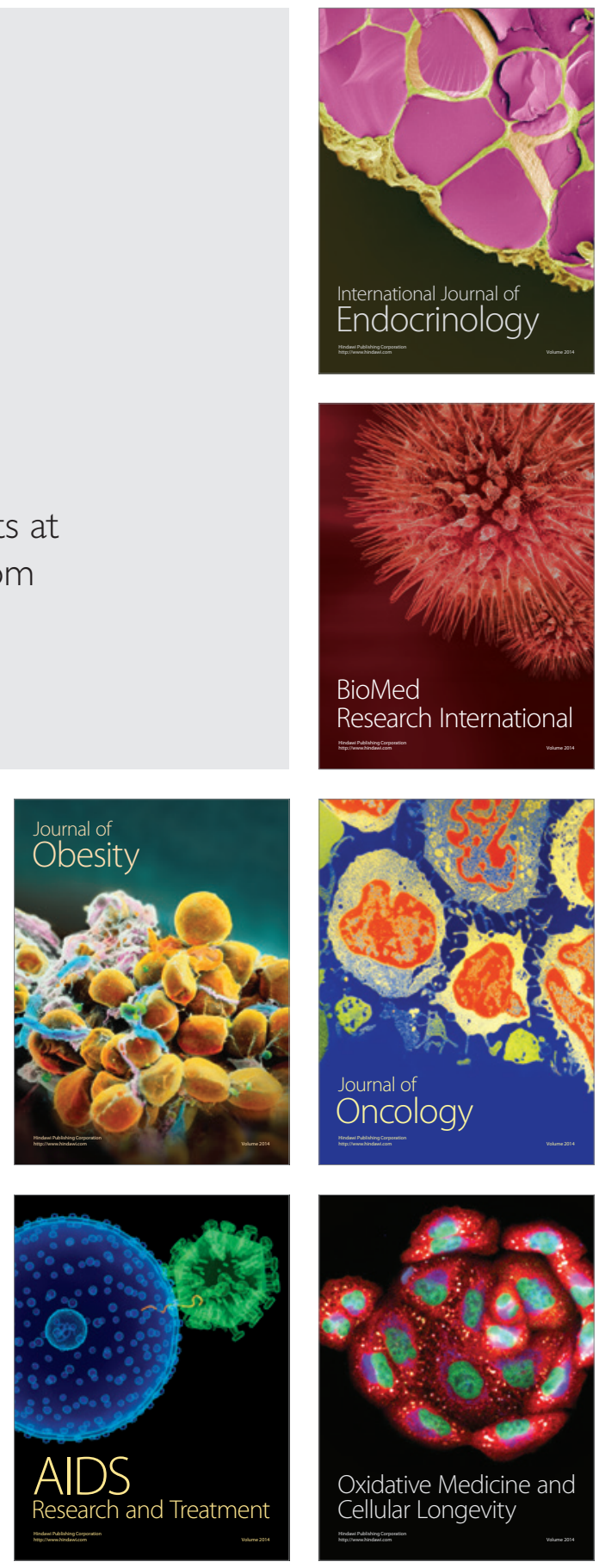